\title{
Comparison of Production Costs in the Financial Statements PT Japfa Comfeed Indonesia Tbk With PT Charoen Pokphand Indonesia Tbk Using Number Index
}

\author{
Insan Kamil ${ }^{1, *}$, Widiya Astuti Alam Sur ${ }^{2}$, Tekad Budiantoro ${ }^{3}$ \\ ${ }^{1,2,3}$ Departemen Economics and Business, Politeknik Negeri Tanah Laut, Indonesia
}

\begin{abstract}
Article Info
Article history:

Received Oct 1, 2020

Revised February 14, 2020

Accepted April 25, 2021

\section{Keywords:}

PT Japfa Comfeed Indonesia Tbk

PT Charoen Pokphand

Indonesia Tbk

ABSTRACT

This study used a relatively simple price and an unweighted aggregate price index number used to calculate the level of production cost annually in the form of a percent. The use of this index number is to compare the current year period divided by the based year and multiplied by $100 \%$. The purpose of this study is to analyze the comparison of production costs from animal feed companies in Indonesia, namely PT Japfa Comfeed Indonesia. Tbk and PT Charoen Pokphand Indonesia Tbk in 2014-2018 with 2014 as the base year. Based on the calculation of production costs using the index number method at PT Japfa Comfeed Indonesia Tbk and PT Charoen Pokphand Indonesia Tbk there is an increase and decrease in production costs. PT Charoen Pokphand Indonesia Tbk has better production costs than PT Japfa Comfeed Indonesia Tbk because the profits of PT Charoen Pokphand Indonesia Tbk company have increased more than PT Japfa Comfeed Indonesia Tbk every year.
\end{abstract}

Production Cost

Index Figures

Comparison

This is an open-access article under the CC BY-SA license.

\section{Corresponding Author:}

Insan Kamil,

Department of Accounting,

Politeknik Negeri Tanah Laut,

Jl. A. Yani Km 6, Desa Panggung, Tanah Laut, Kalimantan Selatan, Indonesia, 70185.

Email: insankml20@politala.ac.id

\section{INTRODUCTION}

Today manufacturing companies are confronted with increasing competition, increasing technology changes, and increasing customers' expectations [1]. A strong manufacturing industry can bring strong economic development to a country [2].

A manufacturing company is a company whose activities are to process raw materials or raw materials into finished goods that are ready for sale. The development of manufacturing companies in Indonesia is growing very rapidly, this is because the manufacturing sector is seen as one of the drivers of the economy and also utilizes abundant natural resources (SDA) so that it is expected to absorb labor in Indonesia. In the manufacturing industry, where technology is changing every day, a firm needs to exchange knowledge and technology [3]. The manufacturing company is looking for a solution to assess the level of sustainable development in the enterprise [4].

According to the Ministry of Industry of the Republic of Indonesia, manufacturing companies are growing rapidly from various regions in Indonesia. Manufacturing companies are divided into several, namely medium manufacturing companies and large manufacturing companies. Medium manufacturing companies are companies that have a workforce of 20 to 99 people, while large manufacturing companies are companies that have a workforce of 100 people or more. 
Manufacturing companies listed on the Indonesia Stock Exchange (IDX) are grouped into several types into sectors and sub-sectors. There are 3 manufacturing sectors, namely: Miscellaneous Industries, Consumer Goods Industry, and Basic Industry \& Chemicals. Each of these manufacturing sectors has several subsectors.

The miscellaneous industry sector has 6 sub-sectors (machinery \& heavy equipment, automotive \& components sub-sector, textile \& garment sub-sector, footwear sub-sector, cable sub-sector, and electronics sub-sector), consumer goods industry sector has 8 subsectors (sub-sector the food \& beverage sector, the cigarette sub-sector, the pharmaceutical sub-sector, the cosmetics \& household goods sub-sector, and the household appliances sub-sector), the basic \& chemical industry sector has 8 subsectors (cement sub-sector, ceramics sub-sector, porcelain $\&$ glass, metal \& similar sub-sector, chemical sub-sector, plastics $\&$ packaging sub-sector, animal feed sub-sector, wood \& processing sub-sector, and pulp \& paper sub-sector). This increased variety also increases the operational complexity of the manufacturing system since every product variant would likely require a different set of operations. As this happens for a few units at a time, controlling the manufacturing environment becomes a demanding task [5]. There are various kinds of sectors and sub-sectors in manufacturing companies that are spread throughout Indonesia, one of which is the animal feed sub-sector. The basic industry \& chemical sector in the animal feed sub-sector in Indonesia is one of the parts that affect the livestock industry because the livestock industry needs animal feed such as pellets, bran, etc. So, do not be surprised if there is competition between companies to create the best products. Animal feeds are formulated to provide essential nutrients necessary for optimal growth and reproduction [6]. Feed is an important aspect of animal husbandry, and commercial feeds are commonly packaged to protect them from moisture and external contamination [7].

Based on a report from www.sahamok.com, about 600 animal feed sub-sector manufacturing companies in Indonesia, but only 4 of them go public or are listed on the Indonesia Stock Exchange, these companies are PT Charoen Pokphand Indonesia Tbk, PT Japfa Comfeed Indonesia Tbk, PT Malindo Feedmill Tbk, and PT Siearad Produce Tbk. The four companies are seen from the largest annual revenue, namely at PT Japfa Compeed Indonesia Tbk and PT Charoen Pokphand Indonesia Tbk, where the increase in the company's revenue in 2018 was IDR 34,012,965,000 and IDR 53,957,604,000 respectively, while PT Malindo Feedmill Tbk amounting to IDR 6,705,892,735 and PT Siearad Produce Tbk in the amount of IDR 3,120,459,000. Revenue from the company is obtained from the products that are made, so that from the products that are made the company must pay costs during the production of animal feed.

Determination of cost is very important because it can affect the company at their economic level. The estimation of cost is performed at the very initial stages of product development. And those are later used for detailed estimation of cost [8]. This is important as the cost level is the main indicator of the competitiveness of the industry in a specific country [9]. Innovation becomes the only constant for a successful and competitive organization [10].

Production costs have several elements, namely raw material costs, labor costs, and costs overhead factory. Raw material costs are all raw material costs that form into finished products and are included explicitly in calculating product costs, labor costs are labor costs that convert raw materials directly into finished products and can be properly charged to certain products and costs. The overhead factory is a production cost that is used to pay for indirect materials and indirect employees. Many methods have been developed constantly to assess product and process quality levels, to compare their competitiveness [11].

Based on the explanation above, the authors took two manufacturing companies in the animal feed sub-sector, namely PT Japfa Comfeed Indonesia Tbk and PT Charoen Pokphand Indonesia Tbk. The two companies are the largest manufacturing companies in Indonesia and also seen in terms of income per year from these companies, so the authors want to observe the comparison of the production costs of animal feed processing in the financial statements of PT Japfa Comfeed Indonesia Tbk and PT Charoen Pokphand Indonesia Tbk from 2014 to 2018 using index numbers so that the authors raised the title of the research journal, namely "Comparison of Production Costs in the Financial Statements of PT Japfa Comfeed Indonesia Tbk with PT Charoen Pokphand Indonesia Tbk Using the Index Number Method". The results of this study are expected to compare the development of production costs of each company.

\section{RESEARCH METHOD}

The process of making this paper has several stages, from data collection techniques, research steps, and data processing. The following is the process of making paper: 


\subsection{DATA COLLECTION TECHNIQUES}

a. Literature Study

According to Nazir (2014) literature study is a data collection technique by duplicating the reviewers' studies of books, literature, records, and reports that had to do with the problem is solved [12]. This technique is used to obtain the basics and opinions in writing which is done by studying various literature related to the problem under study. This is also done to obtain secondary data that will be used as a basis for comparison between theory and practice in the field. Secondary data through this method is obtained by browsing the internet, reading various literature, review results from previous research, lecture notes, and other relevant sources.

b. Documentation

According to Syaodih (2012), a documentation study is a data collection technique by collecting and analyzing documentary documents, both written documents, images, and electronics [13]. This study collects the documents of the financial statements of PT Japfa Comfeed Indonesia Tbk and PT Charoen Pokphand Indonesia Tbk.

\subsection{RESEARCH PROCESS}

Steps The steps of this research have several stages, namely as follows:

a. Literature Study

The first step in this research is that the author searches for references based on literature, papers, journals, and information related to production costs, which support this research.

b. Data Collection

Data collection is in the form of financial reports from PT Japfa Compeed Indonesia Tbk and PT Charoen Pokphand Indonesia Tbk from 2014 to 2018. The financial statement data is obtained from the official website of the Indonesia Stock Exchange (IDX).

c. Data Processing

Data processing in this study is by using the index number method in the relatively simple price index figure model and the unweighted aggregate price index figure, where 2014 is the base year and 2015 to 2018 is the current year of each. - each company.

d. Data Analysis

The data that has been processed then analyzed the development of each production cost at the companies PT Japfa Compeed Indonesia Tbk and PT Charoen Pokphand Indonesia Tbk. The writing of this final project uses hardware and software. The hardware used in this research journal is to use Notebook Acer V5. While the software used is Microsoft Word 2013 for writing the final and project Microsoft Excel 2013 for data processing.

e. Comparison of Data Analysis Results

The results of the data that have been analyzed from each company are comparisons of the production costs of the two related companies from 2015 to 2018.

\subsection{DATA PROCESSING}

According to Supranto (2008), the purpose of making index numbers is to quantitatively measure the occurrence of changes in two different times, such as the price index to measure price changes, the cost index, the cost of living index to measure the inflation rate, and so on. In the index number model, there are several formulas [14]. Based on the method of determination, the index numbers are grouped into 3, namely:

1) Unweighted Price Index Figures An unweighted

2) Price-WeightedFigures A-weighted

3) Chain Price Index Number Chain

In the explanation above the author uses an unweighted price index figure. The reason the authors chose the unweighted price index number was that the data used were by the variables in the unweighted index figure, while the weighted price index numbers and the chain price index numbers did not match the data obtained. The formula for the unweighted price index number is as follows:

a. Simple Relative Price Index Number 


$$
\mathrm{I}_{\mathrm{t}, 0}=\frac{\mathrm{P}_{\mathrm{t}}}{\mathrm{P}_{0}} \mathrm{X} 100 \% \ldots \text { (1) }
$$

It, 0 : Price index at time $t$ with base period 0

$$
\mathrm{P}_{\mathrm{t}} \text { : Price in period } \mathrm{t}
$$

$\mathrm{P}_{0}$ : Price in the base period

b. Unweighted Aggregative Price Index Figures

$$
\mathrm{I}_{\mathrm{t}, 0} \quad=\frac{\sum \mathrm{P}_{\mathrm{t}}}{\sum \mathrm{P}_{0}} \mathrm{X} 100 \% \ldots .
$$

$\mathrm{I}_{\mathrm{t}, 0}$ : Price index at time $\mathrm{t}$ with base period 0

$\sum \mathrm{P}_{\mathrm{t}}$ : Total prices in period $\mathrm{t}$

$\sum \mathrm{P}_{0}$ : Total prices in the base period

\section{RESULTS AND DISCUSSION}

The following is the result of the calculation of production costs which include raw material costs, labor costs, and factory overhead costs using relatively simple price index figures while the unweighted aggregate price index figures calculate the total number of elements of these production costs.

\subsection{The results of processing and analysis of production costs of PT Japfa Comfeed Indonesia Tbk use relatively simple price index figures, namely as follows:}

Table 1. Results of Production Cost Processing Using Simple Relative Price Index Figures

\begin{tabular}{|c|c|c|c|c|}
\hline \multirow{2}{*}{ Costs for } & \multicolumn{4}{|c|}{ Year } \\
\cline { 2 - 5 } & $\mathbf{I}_{\mathbf{2 0 1 5 , 2 0 1 4}}$ & $\mathbf{I}_{\mathbf{2 0 1 6}, \mathbf{2 0 1 4}}$ & $\mathbf{I}_{\mathbf{2 0 1 7}, \mathbf{2 0 1 4}}$ & $\mathbf{I}$ I2018,2014 \\
\hline Raw Material & $(2.98 \%)$ & $2.09 \%$ & $16.89 \%$ & $27.41 \%$ \\
\hline Labor & $42.18 \%$ & $55.06 \%$ & $90.87 \%$ & $65.53 \%$ \\
\hline Overhead Factory & $26.32 \%$ & $25,20 \%$ & $21.97 \%$ & $58.65 \%$ \\
\hline
\end{tabular}

Above can be seen the results of calculations for each production cost (raw material costs, labor costs, and costs overhead factory) every year from 2015 to 2018 using relatively simple index numbers. In 2015 the cost of raw materials decreased by $2.98 \%$, the cause was explained in the financial statements of PT Japfa Comfeed Indonesia Tbk in the report of the directors on page 33 that in 2015 there was a significant increase in the value of the rupiah against the US dollar so that it had an impact on raw materials where the raw materials in the processing of animal feed import from abroad. Quoted from www.cnbcindonesia.com that 2015 experienced a very significant increase where the previous year, namely in 2014 the value of the rupiah currency was Rp. 11,200 and in 2015 it was Rp. 14,700, thus impacting the cost of raw materials at the company PT Japfa Comfeed Indonesia Tbk.

Meanwhile, in 2016, 2017, and 2018 for raw materials, each increased by $2.09 \%, 16.89 \%$, and 27.41\%. In the directors 'report in the financial statements of PT Japfa Comfeed Indonesia Tbk in the 2016 directors' report on page 26, it is explained that the Indonesian government stops importing corn, which is the main raw material for making animal feed, the company is carrying out a pick-up strategy by providing corn drying machines at each factory location several corn centers to obtain corn raw materials of better quality and to make it easier for corn farmers to market their products.

In 2017, the board of directors' report in the financial report on page 82 explains that since mid-2016 the Indonesian government has banned imports of maize as raw material in the animal feed industry, the company provides corn drying facilities in each factory facility and 9 other units located in corn farming centers. ensure the availability of raw materials.

The cost of labor each year has increased from 2015, 2016, 2017, and 2018 respectively by $42.18 \%$, $55.06 \%, 90.87 \%$, and 65.53\%. A researcher named N. Georgy Mankiw in 2007 in his book entitled macroeconomics said that if the labor costs used were higher, the income would be more and more, this is in line with the results of the research that the author made [15]. The processing results for labor costs at PT Japfa Comfeed Indonesia Tbk have increased every year, causing the company's revenue to also increase. Revenues 
in 2014 amounted to IDR 24,458,850, 2015 IDR 25,022,913, 2016 IDR 27,063,310, 2017 IDR 29,602,688, and 2018 IDR 34,012,965.

Costs overhead Each year, the factory increased in 2015 to 2018 by $26.32 \%, 25.20 \%, 21.97 \%$, and $58.65 \%$, respectively. If a company experiences an increase in costs overhead factory, the company incurs large costs and vice versa, if the company in costs overhead factory decreases, the company incurs a small cost. As shown in table 1. on costs of the overhead factory had passed so that PT Japfa Comfeed Indonesia Tbk have to spend a large part in financing expenses in the overhead factory (such as the cost of repairing the machine, etc.).

3.2 The results of the processing and analysis of the total cost of production of PT Japfa Comfeed Indonesia Tbk using aggregative price index figures are not weighted as follows:

Table 2. Results of Treatment Total Production Costs Using aggregated Price Index Numbers Not Weighted

\begin{tabular}{|c|c|c|c|c|}
\hline \multirow{2}{*}{ Costs } & \multicolumn{4}{|c|}{ Year } \\
\cline { 2 - 6 } & $\mathbf{I}_{\mathbf{0 1 5 . 2 0 1 4}}$ & $\mathbf{I}_{\mathbf{2 0 1 6} \mathbf{2 0 1 4}}$ & $\mathbf{I}_{\mathbf{2 0 1 7}, \mathbf{2 0 1 4}}$ & $\mathbf{I}_{\mathbf{2 0 1 8 , 2 0 1 4}}$ \\
\hline Total Production Costs & $0.29 \%$ & $4.92 \%$ & $18.43 \%$ & $30.75 \%$ \\
\hline
\end{tabular}

Above, it can be seen the results of calculating the total production costs each year from 2015 to 2018 using the aggregate price index numbers not he considered an increase. This is because the number of products made has increased every year. It is in line with Carter'swho stated that the level of profit a company receives can be determined by the number of products produced.

3.3 The results of processing and analysis of production costs of PT Charoen Pokphand Indonesia Tbk use relatively simple price index numbers, namely :

Table 3. Results of Production Cost Processing Using Simple Relative Price Index Figures

\begin{tabular}{|l|c|c|c|c|}
\hline \multirow{2}{*}{ Costs for } & \multicolumn{4}{|c|}{ Year } \\
\cline { 2 - 5 } & $\mathbf{I}_{2015,2014}$ & $\mathbf{I}_{\mathbf{2 0 1 6}, 2014}$ & $\mathbf{I}_{\mathbf{2 0 1 7}, 2014}$ & $\mathbf{I}_{\mathbf{2 0 1 8 , 2 0 1 4}}$ \\
\hline Raw Materials & $(2.22 \%)$ & $11.42 \%$ & $16.70 \%$ & $18.32 \%$ \\
\hline Labor & $2.78 \%$ & $24.78 \%$ & $50.61 \%$ & $62.37 \%$ \\
\hline Overhead Factory & $(5.38 \%)$ & $9.65 \%$ & $54.60 \%$ & $66.15 \%$ \\
\hline
\end{tabular}

Above, we can see the results of the calculations for each of the production costs (raw material costs, labor costs, and costs overhead factory) for each. years from 2015 to 2018 using relatively simple index numbers. In 2015, raw material costs decreased by 2.23\%, the cause was in 2015, which was explained in the report of the directors of PT Charoen Pokpand Indonesia Tbk on page 9 of the 2015 financial report, it was stated that the price of raw materials in US dollars was quite high. Quoted from www.cnbcindonesia.com that 2015 experienced a significant increase in the value of the rupiah currency where the previous year, namely in 2014 the value of the rupiah was IDR 11,200 and in 2015 it was IDR 14,700 so that it had an impact on the cost of raw materials at the company PT Charoen Pokphand Indonesia Tbk.

Meanwhile, in 2016, 2017, and 2018 the cost of raw materials increased by $2.09 \%, 16.89 \%$, and $27.41 \%$, respectively. In the financial report of PT Charoen Pokphand Indonesia Tbk in the 2016 directors report on page 5, it is explained that the Indonesian government prohibits direct imports of corn, a raw material for animal feed, as a policy to support self-sufficiency in Indonesian maize, this prohibition affects the availability of maize for animal feed factories, in this challenge. the company applies the right formula for raw material substitution while maintaining the quality expected by breeders throughout Indonesia.

In 2017, the directors' report in the financial report on page 5 explains that the Indonesian government as part of a policy to increase local maize production and towards self-sufficiency has implemented a ban on imports of maize, in this challenge the company has succeeded in minimizing the condition of decreasing the availability of this maize by using a formula that allows the use of ingredients. substitute raw while still maintaining the quality expected by breeders across the country. of 2018 in the report of the directors in the financial statements on page 5, it is explained that the ban on corn imports by the government since 2016 has required the Company to use local maize, from the experience that this company has succeeded in reducing the impact of fluctuations in raw material prices such as applying the right formula for animal feed. through 

substitution of raw materials but still, guarantee high so that breeders throughout Indonesia continue to trust the company's products.

Labor costs have increased each year from 2015, 2016, 2017, and 2018 respectively by $2.78 \%$, $24.78 \%, 50.61 \%$, and 62.37\%. A researcher named N. Georgy Mankiw in 2007 said that if the labor costs used were higher, the income would be more and more, this is in line with the results of the research that the author made [15]. The processing results for labor costs at PT Charoen Pokphand Indonesia Tbk have increased every year, causing the company's revenue to also increase. Revenues in 2014 amounted to IDR 29,150,275, in 2015 amounting to IDR 30,107,727, in 2016 amounting to IDR 38,256,857, in 2017 amounting to IDR 49,367,386, and in 2018 amounting to IDR 53,957,604.

Costs overhead Factory decreased in 2015 and from 2016 to 2018 increased. If a company experiences an increase in costs overhead factory, the company incurs large costs and vice versa, if the company in costs overhead factory decreases, the company incurs a small cost. It can be seen in table 3 . that the costs of the overhead factory have decreased and increased so that PT Charoen Pokphand Indonesia has to pay costs in the overhead factory (for example, such as machine repair costs, etc.).

3.4 Processing results and analysis of the total production costs of PT Charoen Pokphand Indonesia Tbk using the unweighted aggregate price index figures, namely as follows:

Table 4. Processing Results of Total Production Costs Using the Unweighted Aggregative Price Index Number Method

\begin{tabular}{|c|c|c|c|c|}
\hline \multirow{2}{*}{ Costs of } & \multicolumn{4}{|c|}{ Year } \\
\cline { 2 - 5 } & $\mathbf{I 2 0 1 5 , 2 0 1 4}$ & $\mathbf{I 2 0 1 6 , 2 0 1 4}$ & $\mathbf{I 2 0 1 7 , 2 0 1 4}$ & $\mathbf{I 2 0 1 8 , 2 0 1 4}$ \\
\hline Total Production Costs & $(2.57 \%)$ & $11.35 \%$ & $21.87 \%$ & $24.85 \%$ \\
\hline
\end{tabular}

In table 4 can be seen that the results of the calculation of total production costs in 2015 decreased by $2,57 \%$ of this is due to the impact of the value of the rupiah currency has increased significantly and from 2016 to 2018 has increased. 2016 amounted to $11.35 \%, 2017$ amounted to $21.87 \%$, and in 2018 amounted to $24.85 \%$, because the number of products made has increased every year so that the company increased these production costs.

\subsection{Comparative Analysis of Production Costs of PT Japfa Comfeed Indonesia Tbk with PT Charoen Pokphand Indonesia Tbk}

Diagram 5. Comparison of Production Costs of PT Japfa Comfeed Indonesia and PT Charoen Pokphand Indonesia Tbk

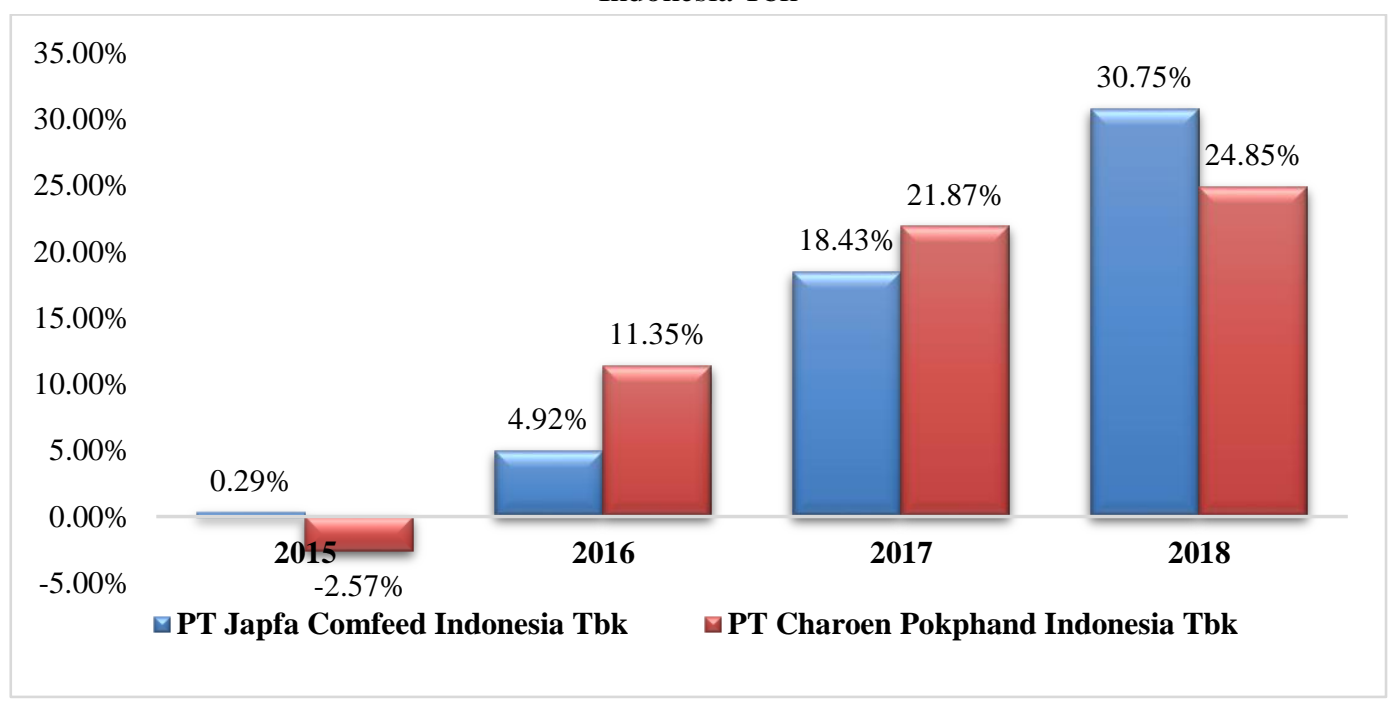

In diagram 5 above, it can be seen that the results of the comparison of total production costs using the unweighted aggregate price index numbers of each company PT Japfa Comfeed Indonesia Tbk with PT Charoen Pokphand Indonesia Tbk start year 2015 to 2018. A comparison of the total production costs of the two companies shows that the company PT Charoen Pokphand Indonesia Tbk has a better total production cost 
because of the amount of profit or profit obtained from PT Charoen Pokphand Indonesia Tbk has increased and the profit is greater. which is earned annually at PT Charoen Pokpand Indonesia Tbk from PT Japfa Comfeed Indonesia Tbk.

Profits generated from the company PT Charoen Pokphand Indonesia Tbk in 2014 amounted to IDR 1,746,644,000, in 2015 amounted to IDR 1,832,598,000, in 2016 amounted to IDR 2,217,856,000, in 2017 amounted to IDR 2,463,628, in 2018 IDR 4,599. 333. Meanwhile, PT Japfa Comfeed Indonesia Tbk earned a profit in 2014 amounting to Rp. 371,288,000, in 2015 amounting to Rp. 524,484,000, in 2016 amounting to Rp. 2,171,608,000, in 2017 amounting to Rp. 1,107,810,000, and in 2018 amounting to Rp. 2,253,201,000 .

In line with research conducted by Asep Mulyana entitled "The Effect of Production Costs on Gross Profits" the results of this study show that production costs have a significant effect on profits or profits [16]. In addition, in the theory put forward by Carter, which states that the level of profit earned by the company can be determined by the volume of products produced, with an increase in production costs, the number of products produced also increases and will result in a profit or profit from the company. So indirectly increasing production costs will also increase the profits earned by the company.

\section{CONCLUSION}

Based on the results of the research that has been conducted by the author, it can be concluded that:

1) Processing of production costs using the index number method in 2014 to 2018 where 2014 is the base year at PT Japfa Comfeed Indonesia Tbk and PT. Charoen Pokphand Indonesia Tbk. The use of the method of price index numbers is relatively simple and the aggregate price index numbers are not weighted comparing the current year period divided by the base year and multiplied by $100 \%$, from these results it is obtained an increase or decrease in production costs in each company.

2) PT Japfa Comfeed Indonesia Tbk in 2015 has decreased raw material costs, 2016 to 2018 has increased. Labor costs and costs overhead factory have increased every year, while for PT Charoen Pokphand Indonesia Tbk, raw material costs have decreased in 2015, 2016 to 2018. Labor costs have increased every year, and costs overhead factory have decreased in 2015, and from 2016 to 2018 have increased.

3) Comparison of the total production costs of PT Japfa Comfeed Indonesia Tbk with PT Charoen Pokphand Indonesia Tbk shows that PT Charoen Pokphand Indonesia Tbk has better production costs because the profit earned from PT Charoen Pokphand Indonesia Tbk has increased greater than PT Japfa Comfeed Indonesia Tbk.

\section{ACKNOWLEDGEMENTS}

To Mrs. Widiya Astuti Alam Sur, S, Pd., M.Sc and Mr. Tekad Budiantoro, S.Pd., M.Pd as my supervisor who provided guidance, advice, and knowledge in making this research journal to completion.

\section{REFERENCES}

[1] D. Alves, L. P. Ferreira, T. Pereira, J. C. Sá, F. J. G. Silva, and N. O. Fernandes, "Analysis and improvement of the packaging sector of an industrial company," Procedia Manuf., vol. 51, pp. 1327-1331, 2020, doi: 10.1016/j.promfg.2020.10.185.

[2] Y. Chen, M. Wang, C. Feng, H. Zhou, and K. Wang, "Total factor energy efficiency in Chinese manufacturing industry under industry and regional heterogeneities," Resour. Conserv. Recycl., vol. 168, no. July, p. 105255, 2021, doi: 10.1016/j.resconrec.2020.105255.

[3] T. Obradović, B. Vlačić, and M. Dabić, "Open innovation in the manufacturing industry: A review and research agenda," Technovation, vol. 102, 2021, doi: 10.1016/j.technovation.2021.102221.

[4] J. Patalas-maliszewska, H. Łosyk, J. Patalas-maliszewska, P. Hanna, H. Łosyk, and H. Łosyk, "ScienceDirect A Sustainable Development Evaluation Card for a Manufacturing Company Evaluation Card Card for for a a Manufacturing for a Manufacturing for a," IFAC Pap., vol. 53, no. 2, pp. 10468-10473, 2020, doi: 10.1016/j.ifacol.2020.12.2790.

[5] O. Rincon-Guevara, J. Samayoa, and A. Deshmukh, "Product design and manufacturing system operations: An integrated approach for product customization," Procedia Manuf., vol. 48, pp. 54-63, 2020, doi: 10.1016/j.promfg.2020.05.020.

[6] L. R. Munoz, W. J. Pacheco, R. Hauck, and K. S. Macklin, "Evaluation of commercially manufactured animal feeds to determine presence of Salmonella, Escherichia coli, and Clostridium perfringens," J. Appl. Poult. Res., vol. 30, no. 2, p. 100142, 2021, doi: 10.1016/j.japr.2021.100142.

[7] R. Wang, Y. Huang, S. Dong, P. Wang, and X. Su, "The occurrence of bisphenol compounds in animal feed plastic packaging and migration into feed," Chemosphere, vol. 265, no. xxxx, p. 129022, 2021, doi: 10.1016/j.chemosphere.2020.129022. 
[8] S. Nandhakumar, R. Thirumalai, J. Viswaaswaran, T. A. Senthil, and V. T. Vishnuvardhan, "Investigation of production costs in manufacturing environment using innovative tools," Mater. Today Proc., vol. 37, no. Part 2, pp. 1235-1238, 2020, doi: 10.1016/j.matpr.2020.06.433.

[9] A. Iversen, F. Asche, Ø. Hermansen, and R. Nystøyl, "Production cost and competitiveness in major salmon farming countries 2003-2018," Aquaculture, vol. 522, no. February, p. 735089, 2020, doi: 10.1016/j.aquaculture.2020.735089.

[10] F. J. Brandl, K. S. Ridolfi, and G. Reinhart, "Can we adopt the toyota kata for the (re-)design of business processes in the complex environment of a manufacturing company?," Procedia CIRP, vol. 93, pp. 838-843, 2020, doi: 10.1016/j.procir.2020.03.086.

[11] E. C. Fernandes, L. I. Dos Santos, J. A. Camatti, L. Brown, and M. Borsato, "Flexible production data generator for manufacturing companies," Procedia Manuf., vol. 51, no. 2020, pp. 1478-1484, 2020, doi: 10.1016/j.promfg.2020.10.205.

[12] M. Nazir, METODE PENELITIAN. Bogor: Gahalia Indonesia, 2014.

[13] N. S. Sukmadinanta, Metode Penelitian Pendidikan. Bandung: PT Remaja Rosdakarya, 2012.

[14] Supranto, Statistik: Teori dan Aplikasi. Jakarta: Erlangga, 2018.

[15] N. G. Mankiw, Makroekonomi, Ke 6. Jakarta: Erlangga, 2007.

[16] A. Mulyana, Pengaruh Biaya Produksi Terhadap Laba Kotor. Jakarta: PT Raja Grafindo Persada, 2018.

\section{BIOGRAPHIES OF AUTHORS (10 PT)}

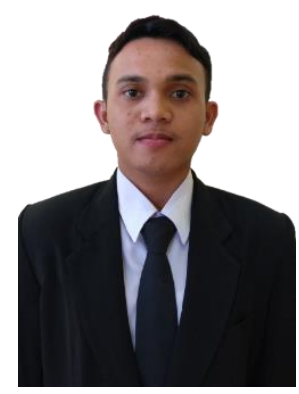

Insan Kamil, place and date of birth in Asam-Asam, March 20, 1998. The author is an alumni of the Accounting study program at Politeknik Negeri Tanah Laut class of 2017. The author studied at SD Negeri Asam-Asam 6 and graduated in 2010, SMP Negeri 2 Jorong graduated in 2013, and SMA Negeri 1 Tanjung graduated in 2016. The author is active in the Accounting Student Association organization "LABA" at Politeknik Negeri Tanah Laut and Capital Market Study Group.

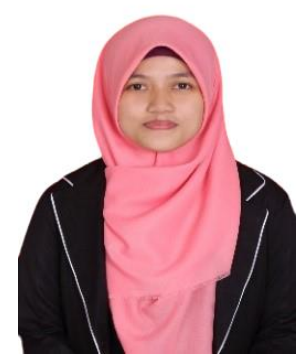

Widiya Astuti Alam Sur, S.Pd., M.Sc., Place and date of birth in Gunturu, October 14, 1991. The author is a permanent lecturer at Politeknik Negeri Tanah Laut. The author studied the Undergraduate Program (S1) in the Mathematics Department, Mathematics Education Study Program at the State University of Makassar and graduated in 2013. Completed his Masters in Mathematics education at Universitas Gadjah Mada, and graduated in 2018. The author teaches Financial Mathematics, Engineering Mathematics courses, and Logic Informatics in the Politeknik Negeri Tanah Laut.

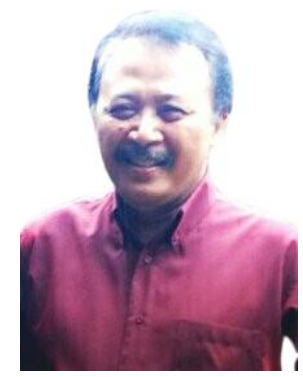

Tekad Budiantoro, S.Pd., M.Pd., place of birth date in Ponorogo, May 4, 1962. The author is a permanent lecturer at Politeknik Negeri Tanah Laut. Undergraduate education took the Indonesian Language Department undergraduate at the College of Teacher Training and Education - PGRI Banjarmasin graduated in 1998. The Master's Program in the Indonesian Language Education Department was taken at Universitas Lambung Mangkurat, graduating in 2011. Subjects being taught are Indonesian Language Courses and Work Writing Scientific in all study programs of the Politeknik Negeri Tanah Laut. 